Article

\title{
Impact of Government Subsidies on Manufacturing Innovation in China: The Moderating Role of Political Connections and Investor Attention
}

\author{
Shuang Wang, Shukuan Zhao *, Dong Shao and Hongyu Liu(D) \\ School of Management, Jilin University, Changchun 130022, China; shuangwang10@163.com (S.W.); \\ shaodong16@mails.jlu.edu.cn (D.S.); hongyul17@mails.jlu.edu.cn (H.L.) \\ * Correspondence: zhaosk@jlu.edu.cn
}

Received: 21 August 2020; Accepted: 17 September 2020; Published: 18 September 2020

check for updates

\begin{abstract}
Although government subsidies have gradually become a crucial means of endorsing public innovation policies, there remains no unified conclusion on the mechanism of their role in enterprise sustainable innovation investment. Employing sample data of listed Chinese manufacturing companies between 2011 and 2019, this study aims to discuss the incentive effect of government subsidies on enterprise innovation investment based on different enterprise ownership. With the combination of resource dependency theory and stakeholder theory, the findings suggest that the intensity of government subsidies exerts an incentive effect on corporate innovation investment; however, the incentive effect is different under the influence of political connections and investor attention. In particular, political connections inhibit the incentive effect and investor attention promotes the incentive effect. Overall, this study provides empirical evidence for the rational allocation of resources by the Chinese government and the acquisition of innovation investment by enterprises of different ownerships and the development of innovation capabilities.
\end{abstract}

Keywords: government subsidies; political connections; investor attention; innovation investment

\section{Introduction}

Innovation is a crucial way for enterprises to augment competitiveness, attain survival, and achieve sustainable development [1]. Enterprise research and development (R\&D) and innovation is one of the hot topics in academic and practical circles at this stage. With the progress of China's strategy of "Mass Entrepreneurship and Innovation," the transition from "Made in China" to "Created in China" has become a crucial path for industrial transformation and upgrading. Innovative enterprises are the foundation of the construction of an innovative country. The development of their innovation performance not only warrants their own efforts, but also depends on the support of government policies [2]. The majority of countries promote enterprise innovation through government-funding for corporate R\&D. In a free market, inadequate $R \& D$ investment due to the externalities of corporate activities is the primary reason that the government actively subsidizes corporate R\&D activities [3]. Therefore, government participation in enterprise innovation activities is a crucial mechanism for dealing with market failures $[3,4]$. The effect of government subsidies on corporate innovation behavior has apparent empirical significance and has been well-demonstrated in theory.

An important factor driving enterprise competitiveness and market economy is innovation [5]. The well-known view that market failure will prevent enterprises from reaching the socially optimal level of R\&D has been put forward by economists to justify public R\&D expenditures by means of public subsidies [6]. For this reason, governments design public R\&D funding to incentivize enterprises' R\&D activities in many countries. According to David [7], the public R\&D funding was about $18.5 \%$ 
in Japan, 30\% in the United States, and 35\% in the EU27 from the 1990s to the 2000s. Furthermore, a considerable part of the R\&D activities of enterprises are funded by these public funds. In terms of the discovery and diffusion of new technologies, the investment of enterprise R\&D departments plays a crucial role in this process [8]. R\&D projects with social value may also be ignored by companies, even if the capital market could be gradually improved and innovation could be fully appropriated [9]. Therefore, public R\&D investment may fund projects that have low economic returns to enterprises but are meaningful to society. In order to prove the effectiveness of public R\&D projects, a large body of scholars have done extensive empirical research. The main focus is on the effect of public R\&D subsidies on corporate R\&D behavior, that is, whether it is an additional "supplement" to R\&D expenses or a "crowding out" to private R\&D investment [7].

Barney and Cynthia proposed two underlying assumptions about resource-based theory, as follows: (i) Resources are heterogeneously distributed in several enterprises, and (ii) these resources are sticky and will not be transferred between enterprises without an agency cost $[10,11]$. The distinct resources of an enterprise are the basis on which the enterprise can form a competitive advantage and realize strategic management [12]. Meanwhile, however, it also causes agency costs in terms of the company's innovative behavior [13]. Integrating agency theory and the resource dependence theory perspective, companies with various resources have diverse innovation intensities and innovation needs $[14,15]$. Therefore, this study has crucial practical significance for enabling the government to select incentive policies to explore the internal logical relationships between government subsidies, corporate internal political connections, corporate external investors' attention, and corporate innovation investment.

Moreover, academia has realized the significance of government subsidies for promoting corporate innovation and broad literature exploring the role of entrepreneurship policy. Nevertheless, in terms of whether R\&D subsidies squeeze into or out of the company's R\&D investment, the pertinent research conclusions are debatable. The research evidence provided has demonstrated that government subsidies can decrease the innovation costs and risks of enterprises, thereby promoting more innovation investment [16]. Conversely, other scholars have reported that government innovation subsidies exert a crowding-out effect on corporate R\&D investment, decreasing the industry's R\&D investment level. In addition, Montmartin and Herrera [17] highlighted that the impact of R\&D subsidies on corporate R\&D activities is unclear. Furthermore, several issues about the validity and efficacy of these specific interventions are yet to be completely explored [18]. In the context of China, limited empirical analyses of manufacturing enterprises with different ownerships exist. Meanwhile, whether the government is influenced by political connection and investors' attention when it intervenes in the process of enterprise innovation to invest more in R\&D and, consequently, enhance their economic and technological performance, remains a challenging empirical question. In particular, research on this challenge is especially severe in emerging economies.

In this study, our main findings are illustrated as follows. From the viewpoint of resource dependence, it investigates the correlation between government subsidies and enterprise innovation and offers more reliable evidence on its impact on R\&D investment. In addition, in this study, we found that enterprises with the assistance of government subsidies have a markedly higher investment in innovation than those without government subsidies. Moreover, we investigated the role of corporate political connections in corporate innovation activities based on agency theory. Information asymmetry and the corruption of government agencies might lead to government subsidies selecting companies with no funding value, and there are reasons to speculate that agency problems, such as bureaucratic intervention rent-seeking, might occur during the funding process [19]. This study suggests that political connection hinders the impact of government subsidies on the enterprise innovation input. Moreover, we assessed investors' concerns about the effect of government subsidies on corporate innovation. We found that the Baidu Search Index is markedly higher for enterprises with government subsidies than for other enterprises, suggesting that Chinese investors are much more sensitive to enterprises with government subsidies than other enterprises. Meanwhile, the innovation input of enterprises is higher when the investors' attention is greater. Our analysis indicates that investors' 
concern and political connection exert a crucial influence on the innovation performance of enterprises, both externally and internally, and delivers crucial implications with respect to entrepreneurs, investors, and policymakers. In a nutshell, our findings highlight that government subsidies play an indispensable role in enterprise innovation activities. Furthermore, we underscore that the influence of Chinese government subsidies on enterprise innovation activities is not markedly different among enterprises of different ownerships.

This study contributes to theory and practice in three ways. First, this research contributes to the existing theory in multiple ways. We combine agency theory and resource dependence theory to elucidate corporate innovation more completely than either theory could alone; there is limited empirical research on the joint investigation of these two theories. The simultaneous testing can endorse the development of theory in this vital field and contribute to a more profound and comprehensive understanding of government policy orientation and corporate strategic choices. Second, this study is part of a growing body of literature on the innovation investment of privileged companies. Moreover, this research further explores the internal connection between government policy orientation under various ownership systems and economic outcomes. Third, the empirical studies were completed by using macroeconomic announcements to assess the crucial role of investor attention. The theoretical literature has demonstrated that investors are more likely to process market-wide information than firm-specific information [20]. However, scholars have only focused on special cases of companies (i.e., earnings announcements) to assess the impact of investor attention [21,22]. As a contribution to both theory and practice, this study is the first to theoretically investigate a critical internal mechanism between the investor attention phenomenon and enterprise innovation with macroeconomic announcements.

\section{Theoretical Analysis and Research Hypothesis}

\subsection{Government and Innovation Investment}

The resource-based theory has become the most influential theory in the past two decades because of its unique insights on a series of issues regarding the existence and development of enterprises and its broad and far-reaching significance for the direction of strategic management thinking [23]. The resource-based theory aims to use "resources" as the core and starting point of corporate strategic decision-making, as well as connect the company's competitive advantages and growth decisions [24]. In addition, the theory has the following two assumptions as its premise: (i) The resources owned by enterprises are heterogeneous, and (ii) these resources have incomplete liquidity among enterprises [25]. Therefore, companies have rare, unique, and difficult-to-imitate resources and capabilities, which can cause long-term differences between different companies. Companies with long-term unique resources are more likely to obtain lasting excess profits and innovative advantages.

Because of the famous view of market failure, companies are unlikely to invest in R\&D projects with the socially optimal amount. In a recent survey, Feldman and Kelley [26] suggested that private investment would lead to higher risks for companies' personal financing decisions. In contrast, public R\&D support projects will be seen as carrying a lower minimum rate of return. Public R\&D policies can be roughly divided into three categories: Direct R\&D subsidies [27], R\&D tax exemptions [6], and support for various forms of cooperation between enterprises, research universities, and high-skilled human capital [7]. Regarding the effect of public R\&D support, the measurement results obtained in earlier studies are ambivalent and there are additional effects or crowding-out effects of public R\&D support on innovation [28]. Czarnitzki et al. [29] concluded that in public R\&D support, tax relief has a positive effect on the R\&D of enterprises. In the research on newly industrialized economies, Yang et al. [30] concluded that public R\&D policies support the innovation of Taiwanese companies. After studying samples from France and Italy, Carboni [31] came to the opposite conclusion that public $R \& D$ support promotes corporate $R \& D$ behavior. Czarnitzki et al. [32] provided similar results for firms in Finland and Germany. 
Indeed, government subsidies are fundamentally an act of government policy intervention and resource redistribution in the market economy. A series of policies are currently used by the government to overcome market failures and reallocate valuable and scarce resources, including direct or indirect funding for enterprise innovation, government-induced innovation projects, and policies related to intellectual property rights [33]. Moreover, public support projects steered by private investment [34], government-led joint partnerships [35], the transformation of scientific research results, and cluster policy are all means by which the government can intervene in market failure and reorganize resources [36].

Government subsidies are the leading means used by the government to optimize resource allocation and intervene in the economy [37]. Of note, government subsidies play a pivotal role in enterprise innovation regarding the introduction of scientific research talents, new product development, and the advancement of new marketing models [38]. In the initial stage of innovative projects, long-term stable capital flow guarantees a reduction of the cash consumption rate and avoids value transfer due to interest payments [39]. Spence [40] concluded that a government's direct R\&D subsidies offer more incentives for corporate innovation than indirect $R \& D$ policies when the spillover effect is adequate in the market. To date, many scholars have comprehensively researched government subsidies in various countries. The Advanced Technology Programs and Small Business Innovation Research in the United States [41], government subsidies in Israel [42], and government-sponsored projects in Finland have garnered considerable attention of academics [43].

Owing to the different content of the clauses of government subsidy projects, the variance in economic conditions in various regions, and the heterogeneity of the research methods adopted by scholars, their conclusions are mixed [6]. Although some exceptions are present, the U.S. government's subsidy projects are usually pessimistic on the input and output of innovation compared with the survey results of European projects [44,45]. Some research data based on the U.S. market illustrated that government subsidies for public R\&D projects exert a crowding-out effect [6]. Some other scholars have inferred that the innovation input and output of enterprises have not been markedly enhanced because of the government innovation subsidies $[35,41,46]$. Despite the large number of pessimistic studies, a small number of studies from emerging economies have indicated that government subsidy programs usually exert a positive impact on corporate innovation, regardless of the fact that they are affected by different factors and varying degrees [42,47]. Concurrently, Innofund endorsed corporate innovation investment in China [48,49]. All these studies reported that government-subsidized companies have more innovation funds in $R \& D$ investment, more innovation outputs, an enhanced innovation performance, and more other investments compared with control group samples [49].

The financing challenges encountered by Chinese companies have a unique impact on corporate innovation. For early Chinese technology companies, Innofund offered considerable innovation start-up capital, without diluting equity [50]. In the 1990s, international trade and foreign investment were considered to be the main source of funding for technological upgrading. In 2006, the Chinese government launched a new innovation plan to increase domestic innovation momentum and reduce the dependence on foreign investment. Therefore, China, as a sample of significant market failures and notable government intervention in emerging economies, is a case worth studying.

Notably, the Chinese government highly participates in the corporate market behavior, particularly in the process of resource allocation. Compared with non-state-owned enterprises in China, state-owned enterprises (SOEs) have more capital, policy, technical, and human resources. Guariglia and Liu [51] reported that the innovation efficiency of Chinese enterprises was adversely affected by financing constraints based on the research results of China's manufacturing panel data between 2000 and 2007. In particular, among non-SOEs, the adverse impact of financing constraints on private enterprises is higher than that of foreign enterprises, whereas SOEs have fewer financial difficulties. Although China's economy has developed noticeably since the implementation of the reform and opening policy, large state-owned banks control the country's financial institutions, and it is challenging for non-SOEs to acquire loans from these weak financial institutions. Young private enterprises, particularly family 
businesses and startups, have a single and more complicated method for obtaining external financing than mature large SOEs [52]. Non-SOEs rely more on government subsidies for various reasons, including the asymmetry of market information [53], lack of guarantee mechanisms and internal financing channels [54,55], and high instability of the external financing environment [56].

Therefore, the following hypotheses are proposed, in accordance with the resource dependence theory:

Hypothesis 1 (H1). Government subsidies positively correlate with innovation investment.

Hypothesis 2 (H2). Compared with SOEs, the government subsidies for non-SOEs exert a stronger effect on promoting enterprise innovation.

\subsection{Political Connection and Innovation Investment}

The stakeholder management theory proposes that the management activities performed by business managers to broadly balance the stakeholders' interests in all aspects are a challenge to the traditional shareholder supremacy theory [57]. The public has closely watched and discussed the relationship between the government and the business community. Government agency subsidies for corporate $R \& D$ projects are a way of realizing resource allocation. Nevertheless, numerous factors in the resource allocation process affect the efficacy of government subsidies [58]. Political connection is one of the crucial means for the close connection between stakeholders in the government and the business community, and is widespread around the globe [59]. Even in developed countries, such as the United States, close ties between companies and politicians are prevalent. Moreover, executives or directors with military or government backgrounds are not uncommon in enterprises [60]. Based on the resume information of the major leaders provided by listed companies, Li and Zhang [61] and Jia [62] regarded the companies whose chairman or CEO was or had been engaged in government work as politically connected companies.

By exploring the situation in various countries, some scholars deduced that companies could obtain competitive advantages and scarce resources from the close relationship with the government, including tax incentives [63], financial support [64], and R\&D subsidies [65]. Faccio et al. [66] suggested that government leaders often use the convenience of private positions to acquire more financial support for related companies to generate sufficient funds for their R\&D activities. To endorse the innovation of domestic enterprises, the Malaysian government formulated the New Economic Policy (NEP) in 1970. Since then, more priority rights and resources have been acquired by politically related enterprises, including signing government cooperation projects, the right to privatize state-owned assets, attaining more government $R \& D$ subsidies, and increasing access to investment channels [67]. In companies with distinct resources, systemic differences in performance closely correlate with the relative value of political connections [64]. Over the past 30 years, it has become increasingly common for Chinese companies to offer director or CEO positions to politically connected officials. Meanwhile, this has gradually been included as part of corporate strategic decisions because of the economic benefits and resource advantages brought about by political connections.

Moreover, the inefficiency of corporate innovation has been attributed to government participation in the redistribution of market resources [58]. Bertrand [67] reported that political connections did not bring considerable innovation benefits to the company in a cross-section. In some cases, to sustain an excellent interactive relationship, political connections led company directors and CEOs to use company resources to assist government officials, in order to augment their political performance, even at the expense of company interests. Based on large-scale global research, Faccio [66] demonstrated that when society is relatively stable, the average innovation performance of politically connected companies is lower than that of non-politically connected companies. Reportedly, the Chinese government's innovation fund has provided financial support to various technological innovation companies; however, people are also increasingly aware of the phenomenon of "zombie companies" defrauding 
government subsidies. Accordingly, the government terminated funding for 1295 projects because these "zombie companies" could not complete the projected goals when applying for the project. Even political manipulation is rampant in non-shell companies. In a survey, Stuart and Wang [68] projected that financial data were manipulated in over half of the projects that applied for Chinese government subsidies. At Hanxin Microprocessor, founder Jin Chen and his family business defrauded 110 million yuan in national R\&D subsidies; an investigation revealed that he and his team never really developed microprocessor design technology. To conceal the false innovation facts, Chen forged experimental data. It is noteworthy that secure political connections provide non-shell companies with an opportunity to defraud government subsidies.

The role of government subsidies under the manipulation of political connections in promoting innovative capabilities of emerging economies is dubious for various reasons. First, in countries with an underdeveloped innovation ecosystem, even if a professional team guides public investment, government subsidies cannot enhance the efficiency of corporate innovation because of the inadequate protection of intellectual property rights and the lack of cross-industry collaboration $[69,70]$. Second, in emerging economies with weak legal systems, organized rent-seeking interest groups tend to use information asymmetry in risk financing to defraud national innovation subsidies [71]. In countries where government officials accountable for investment lack systematic professional technical and commercial information, companies have more opportunity to successfully apply for government subsidies by constructing false information [72]. Third, due to the rapid economic development in the last three decades, the national governance system is flawed, with widespread corruption [73]. To maximize private interests, government officials tend to use public power to apply for R\&D funds for their family businesses or other stakeholders [74]. Even under certain circumstances, the rate of public R\&D project subsidies used for private benefits is as high as $87 \%$ [75].

Theoretically, the nature of ownership causes differences in the innovation goals, inputs, and methods of enterprises. To date, several studies have highlighted the uneven distribution of political resources between SOEs and non-SOEs in China. Compared with the rewards of the natural production rights of SOEs, the political connection of private enterprises is a strategic choice. A majority of studies contend that China is currently in a stage of social transformation, with limitations in formal systems, such as finance and law [76]. Compared with SOEs, political connection as an informal alternative mechanism could help non-SOEs handle development hindrances and promote the efficient allocation of social resources. The common aim pursued by the management of SOEs during their tenure is to maximize personal benefits, not the economic benefits and innovation performance of the enterprise [77]. Therefore, SOEs often invest in productive projects that can generate benefits in the short term and augment their political performance, rather than innovative projects that have long investment income cycles, high risks, and no return during their tenure. Furthermore, private enterprises, with economic goals as their starting point, are more inclined to enhance their competitive advantage by increasing the innovation input [78].

Accordingly, the following hypotheses are proposed, in accordance with stakeholder theory:

Hypothesis 3 (H3). Increased political connection weakens the positive relationship between government subsidies and innovation investment.

Hypothesis 4 (H4). Compared with non-SOEs, the political connection of SOEs exerts a stronger weakening effect on the relationship between government subsidies and enterprise innovation.

\subsection{Investor Attention and Innovation Investment}

With the resource dependence theory, the financial dilemma experienced by Chinese companies has aggravated the state of corporate innovation input and output [79]. Based on the stakeholder theory, ambiguity in innovation prospects and a continuous upsurge in R\&D investment and longer-investment-return time horizons would lower the prediction of investors in terms of the 
investment value. Except for intellectual property rights, no collateral exists for corporate R\&D, which has an increased investors' wait-and-see attitude, making it challenging for companies to obtain funds [80].

In the economics and management literature, the crowding-out effect is extensively discussed using evidence from numerous countries. Some scholars have argued that government subsidies exert a crowding-out effect on enterprise innovation [41]. In a survey, Hall demonstrated that capital market imperfection is the fundamental source of inadequate R\&D investment and that the capitalized value of R\&D did not appear on the company's balance sheet [7]. Usually, the information asymmetry between funded companies and investors can result in investors being unable to directly estimate the return on innovation and unwilling to invest, even if they are promised a high return on investment. Using hybrid metrology methods, González and Pazó [81] analyzed Spanish manufacturing firms and found that no crowding-out effect is a stable result. Furthermore, a study on the impact of government subsidies on Flemish and German R\&D services, business-related services, computer services, and the manufacturing sector rejected the crowding-out hypothesis [82].

Nevertheless, this study discusses the additional effects of government subsidies. A broad range of research on the impact of government subsidies on enterprise innovation has revealed that subsidies stimulate increased investment in innovation for enterprises among recipient firms and induce additional private investment [26,40]. In addition, numerous recent theoretical studies have demonstrated that owing to the limited attention of investors, they selectively focus on information that is available and will affect the innovative behavior of enterprises and the value of assets. Meuleman and De Maeseneire [83] explored the external financing of small- and medium-sized companies in Belgium. For example, in high-tech industries or emerging markets, government subsidies are crucial for inducing private investment as a means of effectively certifying the innovation and competitiveness of enterprises when enterprises are experiencing financing challenges. In an interview with American Advanced Technology Company, a more recent empirical analysis of Feldman and Kelley reported that the likelihood of external investment is driven by government R\&D subsidies, especially for small- and medium-sized firms [26]. Furthermore, Kleer [84] accentuated that, accompanied by quality signals, government subsidies can increase private investments.

Based on the resource-based view theory, the focus of investors is a scarce cognitive resource [85]. Repullo and Suarez [86] indicated that professional risk assessment and financial investors have well-informed information channels, which decrease the financial and moral risks of investment. Nevertheless, not everyone is a professional investor. The government conducts a strict and fair review of project declaration qualifications, helping private investors to save high-risk assessment costs and competently allocate limited resources to potential investment targets [40]. In the case of imperfect capital market investment allocation, investors especially focus on the investment orientation of neutral and authoritative arbitrators, such as the government. Limited research on the database of Chinese listed companies in terms of various ownership companies has focused on the mixed effects of attracting private investment and investment in innovation. Specifically, based on the differences in resource allocation among enterprises of different ownerships, this study aims to comprehensively explore the heterogeneity of the role of innovative enterprises in the attention of investors in SOEs and non-SOEs.

Therefore, the following hypotheses are proposed:

Hypothesis $\mathbf{5}$ (H5). Increased investor attention strengthens the positive relationship between government subsidies and innovation investment.

Hypothesis 6 (H6). Compared with non-SOEs, investors of SOEs focus more on the promotion of the relationship between government subsidies and enterprise innovation. 


\section{Empirical Study Design}

\subsection{Study Context and Sample}

For the analysis, we used Chinese microdata on all of the manufacturing of A-share listed companies in the Shanghai Stock Exchange and the Shenzhen Stock Exchange in 2011 and 2019, inclusive. Compared with service firms or even light manufacturing firms, we only included manufacturing firms because the innovation efficiency is a specifically salient issue for these firms. In this study, the data were obtained from the CSMAR database in China [87]; among them, the data related to corporate politics were obtained from the governance structure sub-database of the CSMAR database. In addition, we extracted the personal resume information of the chairman or general manager of the listed company and manually searched for detailed politics-related information, before classifying and summarizing it. Investor attention data were obtained from the Baidu Search Index on the Baidu website. To avoid the impact of extreme values on the research results, special treatment (ST) companies and companies with missing values of corporate financial data and politically related information were excluded from the analysis. Finally, we obtained 7174 valid observations, of which 2017 were valid for state-owned enterprises (SOEs) and 5157 were valid for non-state-owned enterprises (non-SOEs). To eliminate the influence of outliers, we winsorized all continuous variables at the top and bottom $1 \%$ of the dataset. All data processing was performed with STATA15 software which was produced by StataCorp LLC, in College Station, Texas, USA.

\subsection{Variables}

\subsubsection{Dependent Variable}

Innovation investment. All of our hypotheses dealt with the impact of government subsidies on innovation investment. Innovation investment implies the investment made by an enterprise to perform innovation activities and generate innovation profits, including capital, human resources, and material resources. In 2012, the International Economic Cooperation Organization considered the obtainability of its indicators and the reliability of data; it used innovation investment as the only indicator to measure innovation capabilities [88]. Innovation investment costs comprise direct and indirect costs incurred in innovation activities. Nevertheless, considering the discrepancy of the overall scale of the company, in the existing literature, most studies used the innovation intensity to measure the level of innovation input of the company, that is, the ratio of the company's R\&D input cost to the company's operating income [89]. As most listed manufacturing companies are still in the development and growth period, the operating income denotes the profitability and innovation potential of the company to a certain extent. Therefore, we adopted the enterprise innovation intensity (R\&D investment expense/operating income) to measure the enterprise's innovation investment.

\subsubsection{Independent Variable}

Government subsidies. In this study, government subsidy was the independent variable. Government subsidies are the sum of subsidies received by enterprises, including financial subsidies, financial discounts, tax deductions, and refunds, evaluated by the non-operating income minus the details of government subsidies. Based on noncurrent financial statements of the company, profit and loss and other disclosure reports are used as verification information to calculate the cumulative effect with innovation investment [90]. The data were obtained from the government subsidies of a non-operating income in the annual report of the sample companies. Therefore, we calculated the government subsidies by dividing the government subsidies amount by the operating income for the year [91].

\subsubsection{Moderating Variables}

We included political connections and investor attention as moderating variables in this study. 
Political connections. Political connection is a dummy variable that equals 1 if the chairman or CEO of a company is related to politics; otherwise, it is 0 . To date, several empirical studies have used numerous different methods to measure political connections. For example, Faccio [92] defined political connections as being present when corporate executives or directors have close ties with members of Congress, heads of state, or ministers; the company's management participates in the election in Pakistan; or the company's management has a long-term ally with the president's family in Indonesia. In this study, we considered the characteristics of China's system and defined a politically connected firm as one whose CEO or board chairperson is currently holding, or previously held, a position as a government official, National People's Congress deputy, and Chinese People's Political Consultative Conference member; otherwise, it was 0.

Investor attention. Unlike previous empirical research methods, which used indirect measurement methods, we directly evaluated the limited attention of investors through statistics on Internet search indexes. Closely associated with the previous attention proxy—the Google Search Volume Index-the Baidu Search Engine was developed by Baidu Company, and has the most search users in China [93]. The calculation of the Baidu Search Index is based on the frequency with which users search for keywords each day [94]. We constructed a daily Baidu Search Index as the direct measure of investor attention by manually collecting the searching information from the Baidu Website (http://index.baidu.com). In addition, we used the sum of the stock abbreviation and the stock code of the Baidu Search Index as the proxy variable of investor attention. The sample period was between January 2011 and December 2019. To avoid the problem of heteroscedasticity, it was processed in logarithm.

\subsubsection{Control Variables}

To eliminate alternative explanations, we included several control variables for analysis. First, we incorporated variables that control the financial aspects of the company into our model. We calculated the current ratio by using the ratio of the total current assets to the total current liabilities, which measured the company's capital turnover and profitability. A conflict of interest exists within an enterprise between avoiding debt repayment risks and raising the innovation input. In addition, we included the flow rate ratio of the previous year to control the short-term debt repayment risk (Risk). Considering the likely impact of cash holdings on corporate innovation, we included cash flow (Cash) in the control variables, which is measured by the ratio of net cash flow from operating activities to total assets. Additionally, the solvency was calculated by the ratio of long-term liabilities to total assets, which assesses how many fixed assets a company has for long-term loan mortgage guarantees, in order to examine the degree of security of long-term creditors. We also calculated the return on shareholder's equity (ROE), which is the percentage of net profit to average shareholder's equity, in order to measure the efficiency of the company's use of its own capital.

Meanwhile, we controlled for corporate governance characteristics, as good corporate governance positively affects the company's investment in innovation. As the company's political resources, moral hazard, and innovation decisions are predominantly affected by the proportion of the largest shareholder, we assessed the shareholding ratio of the largest shareholder (Share), that is, the number of shares held by the largest shareholder divided by the total number of shares of the enterprise. As the impact of management's shareholding ratio on the company's innovation investment policy, we evaluated the management shareholding ratio (Mshare), that is, the percentage of management's shareholding to the company's total shares. CEO duality is a dummy variable that equals 1 when the same individual holds the CEO and chairman positions; otherwise, it is 0 . CEO duality implies that the unequal rights of the company's senior management team are relatively high. Therefore, managers can devise effective rules to promote the differentiation of senior management roles and augment the ability of the senior management team to make innovative decisions.

Furthermore, we controlled the corporate ownership structure that could affect the company's investment in innovation. We coded state-owned enterprises (SOEs) for a dummy variable that equals 1 and 0 for non-state-owned enterprises (NSOEs). 


\subsubsection{Dummies}

Finally, we controlled the industry dummy variable and the year dummy variable to prevent the same industry from being included and a contemporaneous correlation. Precisely, we set 20 dummy variables as the standard according to the 2012 industry classification guidelines of the China Securities Regulatory Commission and set a total of nine dummy variables for 2011-2019.

\subsubsection{Empirical Model}

In this study, we tested whether the government subsidy intensity assists firms in generating more innovation investment by implementing fixed-effect panel data regression through the following basic regression models:

Innovation Investment $\mathrm{t}_{\mathrm{i}, \mathrm{t}}$

$$
\begin{aligned}
& =\alpha_{0}+\beta_{1} \times \text { Government Subsidies }_{\mathrm{i}, \mathrm{t}}+\Sigma \text { Control }_{\mathrm{i}, \mathrm{t}}+\text { Year } \\
& + \text { Industry }+\varepsilon_{\mathrm{i}, \mathrm{t}}
\end{aligned}
$$

Innovation Investment $\mathrm{i}_{\mathrm{i}, \mathrm{t}}$

$=\alpha_{0}+\beta_{1} \times$ Government Subsidies $_{\mathrm{i}, \mathrm{t}}+\beta_{2} \times$ Political Connection $_{\mathrm{i}, \mathrm{t}}$

$+\beta_{3} \times$ Government Subsidies $_{i, t} \times$ Political Connection $_{i, t}$

$$
+\Sigma \text { Control }_{i, t}+\text { Year }+ \text { Industry }+\varepsilon_{i, t}
$$

Innovation Investment $\mathrm{t}_{\mathrm{i}, \mathrm{t}}$

$$
\begin{aligned}
& =\alpha_{0}+\beta_{1} \times \text { Government Subsidies }_{\mathrm{i}, \mathrm{t}}+\beta_{2} \times \text { Investor Attention }_{\mathrm{i}, \mathrm{t}} \\
& +\beta_{3} \times \text { Government Subsidies }_{\mathrm{i}, \mathrm{t}} \times \text { Investor Attention }_{\mathrm{i}, \mathrm{t}} \\
& +\Sigma \text { Control }_{\mathrm{i}, \mathrm{t}}+\text { Year }+ \text { Industry }+\varepsilon_{\mathrm{i}, \mathrm{t}}
\end{aligned}
$$

\section{Results and Discussion}

\subsection{Results}

Table 1 presents pairwise correlations and descriptive statistics for the variables. The descriptive statistics demonstrated substantial and statistically significant differences between SOEs and non-SOEs. SOEs attained high scores in terms of investment in innovation, government subsidies, and the degree of investor attention. Nevertheless, regarding political connections, non-SOEs needed to invest more to acquire scarce government resources because of their ownership disadvantages. Meanwhile, the correlation coefficient between the variables is small, and the variance inflation factor (VIF) value of each control variable is less than 2 , suggesting no serious multicollinearity problem. 
Table 1. Descriptive statistics and correlations.

\begin{tabular}{|c|c|c|c|c|c|c|c|c|c|c|c|c|c|c|c|c|c|}
\hline & SD & Mean & $\begin{array}{c}\text { SD } \\
\text { (SOEs) }\end{array}$ & $\begin{array}{c}\text { Mean } \\
\text { (SOEs) }\end{array}$ & $\begin{array}{c}\text { SD } \\
\text { (NSOEs) }\end{array}$ & $\begin{array}{c}\text { Mean } \\
\text { (NSOEs) }\end{array}$ & $\begin{array}{c}\text { Government } \\
\text { Subsidies }\end{array}$ & $\begin{array}{c}\text { Political } \\
\text { Connection }\end{array}$ & $\begin{array}{c}\text { Investor } \\
\text { Attention }\end{array}$ & ROE & Solvency & Share & Mshare & $\begin{array}{c}\text { CEO } \\
\text { Duality }\end{array}$ & $\begin{array}{c}\text { Current } \\
\text { Ratio }\end{array}$ & Cash & Risk \\
\hline $\begin{array}{l}\text { Innovation } \\
\text { investment }\end{array}$ & 0.055 & -0.044 & 0.076 & -0.038 & 0.045 & -0.046 & & & & & & & & & & & \\
\hline $\begin{array}{l}\text { Government } \\
\text { Subsidies }\end{array}$ & 0.025 & -0.013 & 0.030 & -0.012 & 0.023 & -0.014 & $-0.403^{* * *}$ & & & & & & & & & & \\
\hline $\begin{array}{l}\text { Political } \\
\text { connection }\end{array}$ & 0.470 & -0.330 & 0.424 & -0.235 & 0.481 & -0.364 & $-0.038^{* * *}$ & -0.010 & & & & & & & & & \\
\hline $\begin{array}{l}\text { Investor } \\
\text { attention }\end{array}$ & 389.6 & -489.5 & 545.5 & -634.1 & 295.0 & -435.8 & $-0.037^{* * *}$ & $-0.062 * * *$ & $-0.031^{* * *}$ & & & & & & & & \\
\hline ROE & 0.623 & -0.043 & 0.660 & -0.005 & 0.608 & -0.060 & -0.004 & -0.005 & $-0.020 *$ & $-0.051 * * *$ & & & & & & & \\
\hline Solvency & 0.069 & -0.042 & 0.087 & -0.066 & 0.059 & -0.034 & $-0.074^{* * *}$ & -0.009 & -0.016 & $-0.233 * * *$ & $-0.058^{* * *}$ & & & & & & \\
\hline Share & 14.49 & -35.34 & 14.42 & -38.20 & 14.38 & -34.31 & $-0.078^{* * *}$ & $-0.061^{* * *}$ & -0.017 & $-0.071^{* * *}$ & $-0.031^{* * *}$ & -0.009 & & & & & \\
\hline Mshare & 0.203 & -0.147 & 0.027 & -0.005 & 0.214 & -0.198 & $-0.097^{* * *}$ & $-0.066^{* * *}$ & $-0.062 * * *$ & $-0.272 * * *$ & $-0.040 * * *$ & $-0.213 * * *$ & $-0.057^{* * *}$ & & & & \\
\hline COE duality & 0.465 & -0.315 & 0.307 & -0.105 & 0.488 & -0.390 & $-0.074^{* * *}$ & $-0.048 * * *$ & $-0.034 * * *$ & $-0.107^{* * *}$ & $-0.027 * *$ & $-0.078^{* * *}$ & 0.005 & $-0.219 * * *$ & & & \\
\hline Current ratio & 5.178 & -3.242 & 1.888 & -1.914 & 5.855 & -3.718 & $-0.217^{* * *}$ & $-0.183^{* * *}$ & -0.007 & $-0.137^{* * *}$ & $-0.027^{* *}$ & $-0.181^{* * *}$ & -0.010 & $-0.205^{* * *}$ & $-0.095^{* * *}$ & & \\
\hline Cash & 0.300 & -0.138 & 0.315 & -0.078 & 0.291 & -0.161 & $-0.031^{* * *}$ & $-0.034^{* * *}$ & -0.023 * & $-0.054^{* * *}$ & -0.017 & $-0.085^{* * *}$ & $-0.041^{* * *}$ & $-0.118^{* * *}$ & $-0.066^{* * *}$ & $0.067^{* * *}$ & \\
\hline Risk & 0.331 & -0.574 & 0.392 & -0.649 & 0.302 & -0.547 & $-0.081^{* * *}$ & -0.006 & $-0.039 * * *$ & $-0.157^{* * *}$ & $-0.083^{* * *}$ & $-0.389^{* * *}$ & $-0.053^{* * *}$ & $-0.220^{* * *}$ & $-0.087^{* * *}$ & $0.270 * * *$ & 0.011 \\
\hline
\end{tabular}


Table 2 presents the results that were employed to test our hypotheses using ordinary least squares (OLS) models. Hypothesis 1 proposed that corporate government subsidies positively correlate with innovation investment. Model 1 (Table 2) showed that the coefficients for the main effect of government subsidies were positive and significant $(\beta=0.838, p<0.001)$, thereby supporting Hypothesis 1 . In addition, the influence of the main effect was positive and significant in all models, which further supported our hypothesis.

Table 2. Fixed-effect ordinary least squares (OLS) regressions for the influence of government subsidies on innovation investment.

\begin{tabular}{|c|c|c|c|}
\hline & Model 1 & Model 2 & Model 3 \\
\hline Variables & All & SOEs & NSOES \\
\hline Constant & $\begin{array}{c}0.036^{* * *} \\
(0.004)\end{array}$ & $\begin{array}{c}0.022 * * * \\
(0.008)\end{array}$ & $\begin{array}{c}0.040^{* * *} \\
(0.003)\end{array}$ \\
\hline $\mathrm{ROE}$ & $\begin{array}{l}-0.001 \\
(0.001)\end{array}$ & $\begin{array}{c}-0.002^{* * *} \\
(0.001)\end{array}$ & $\begin{array}{l}-0.000 \\
(0.001)\end{array}$ \\
\hline Solvency & $\begin{array}{c}-0.030^{* * *} \\
(0.008)\end{array}$ & $\begin{array}{c}-0.034^{* * *} \\
(0.010)\end{array}$ & $\begin{array}{c}-0.032^{* * *} \\
(0.009)\end{array}$ \\
\hline Current Ratio & $\begin{array}{c}0.001 * * * \\
(0.000)\end{array}$ & $\begin{array}{c}0.004^{* * * *} \\
(0.001)\end{array}$ & $\begin{array}{c}0.001^{* * *} \\
(0.000)\end{array}$ \\
\hline Cash & $\begin{array}{c}-0.005^{* *} \\
(0.002)\end{array}$ & $\begin{array}{l}-0.006 \\
(0.005)\end{array}$ & $\begin{array}{c}0.005^{* * *} \\
(0.002)\end{array}$ \\
\hline Risk & $\begin{array}{c}0.004 \\
(0.006)\end{array}$ & $\begin{array}{l}-0.005 \\
(0.014)\end{array}$ & $\begin{array}{c}0.008^{* * *} \\
(0.002)\end{array}$ \\
\hline Share & $\begin{array}{c}-0.000^{* * * *} \\
(0.000)\end{array}$ & $\begin{array}{l}-0.000 \\
(0.000)\end{array}$ & $\begin{array}{c}-0.000 * * * \\
(0.000)\end{array}$ \\
\hline Mshare & $\begin{array}{l}0.007^{*} \\
(0.004)\end{array}$ & $\begin{array}{c}0.124^{* * * *} \\
(0.045)\end{array}$ & $\begin{array}{c}0.007^{* *} \\
(0.003)\end{array}$ \\
\hline CEO Duality & $\begin{array}{c}0.004^{* *} \\
(0.002)\end{array}$ & $\begin{array}{c}0.007 \\
(0.012)\end{array}$ & $\begin{array}{c}0.004^{* * *} \\
(0.001)\end{array}$ \\
\hline Government Subsidies & $\begin{array}{c}0.838^{* * *} \\
(0.086)\end{array}$ & $\begin{array}{c}0.805^{* * *} \\
(0.183)\end{array}$ & $\begin{array}{c}0.842^{* * *} \\
(0.085)\end{array}$ \\
\hline Observations & 7174 & 2017 & 5157 \\
\hline Year & YES & YES & YES \\
\hline Industry & YES & YES & YES \\
\hline Adjusted $\mathrm{R}^{2}$ & 0.197 & 0.107 & 0.298 \\
\hline
\end{tabular}

Robust standard errors shown in parentheses. ${ }^{* * *} p<0.01,{ }^{* *} p<0.05$, and ${ }^{*} p<0.1$.

Hypothesis 2 proposed that the government subsidies intensity for non-state-owned enterprises has a stronger effect on promoting enterprise innovation comparing with state-owned enterprises. As Model 2 (Table 2) shows, the coefficient of state-owned enterprises is positive and significant ( $\beta=0.805, p<0.001$ ). Model 3 (Table 2 ) shows the coefficient of non-state-owned enterprises is positive and significant $(\beta=0.842, p<0.001)$. The above results support hypothesis 2 .

Hypothesis 3 proposed that political connection negatively moderates the relationship between government subsidies and innovation investment. Model 4 (Table 3 ) showed that the coefficient for the interaction term was significant and negative $(\beta=-0.582, p<0.001)$ when other interactions were added to the model, thereby supporting Hypothesis 3. 
Table 3. The moderation effect of political connection and investor attention on innovation investment.

\begin{tabular}{|c|c|c|c|c|c|c|}
\hline & Model 4 & Model 5 & Model 6 & Model 7 & Model 8 & Model 9 \\
\hline Variables & All & SOEs & NSOEs & All & SOEs & NSOEs \\
\hline Constant & $\begin{array}{c}0.035^{* * *} \\
(0.004)\end{array}$ & $\begin{array}{c}0.022 * * * \\
(0.008)\end{array}$ & $\begin{array}{c}0.038^{* * *} \\
(0.003)\end{array}$ & $\begin{array}{c}0.039 * * * \\
(0.004)\end{array}$ & $\begin{array}{c}0.029 * * * \\
(0.008)\end{array}$ & $\begin{array}{c}0.041 * * * \\
(0.003)\end{array}$ \\
\hline ROE & $\begin{array}{l}-0.001 \\
(0.001)\end{array}$ & $\begin{array}{c}-0.002 * * \\
(0.001)\end{array}$ & $\begin{array}{l}-0.000 \\
(0.001)\end{array}$ & $\begin{array}{l}-0.001 \\
(0.001)\end{array}$ & $\begin{array}{c}-0.002 * * \\
(0.001)\end{array}$ & $\begin{array}{l}-0.000 \\
(0.001)\end{array}$ \\
\hline Solvency & $\begin{array}{c}-0.030^{* * *} \\
(0.008)\end{array}$ & $\begin{array}{c}-0.034^{* * *} \\
(0.010)\end{array}$ & $\begin{array}{c}-0.032 * * * * \\
(0.009)\end{array}$ & $\begin{array}{c}-0.033^{* * *} \\
(0.009)\end{array}$ & $\begin{array}{c}-0.040^{* * * *} \\
(0.010)\end{array}$ & $\begin{array}{c}-0.035^{* * *} \\
(0.009)\end{array}$ \\
\hline Current Ratio & $\begin{array}{c}0.001 * * * \\
(0.000)\end{array}$ & $\begin{array}{c}0.003^{* * * *} \\
(0.001)\end{array}$ & $\begin{array}{c}0.001^{* * *} \\
(0.000)\end{array}$ & $\begin{array}{c}0.002 * * * \\
(0.000)\end{array}$ & $\begin{array}{c}0.004^{* * *} \\
(0.001)\end{array}$ & $\begin{array}{c}0.001 * * * \\
(0.000)\end{array}$ \\
\hline Cash & $\begin{array}{c}-0.005^{* *} \\
(0.002)\end{array}$ & $\begin{array}{l}-0.006 \\
(0.005)\end{array}$ & $\begin{array}{c}-0.005 * * * \\
(0.002)\end{array}$ & $\begin{array}{c}-0.005^{* *} \\
(0.002)\end{array}$ & $\begin{array}{l}-0.006 \\
(0.005)\end{array}$ & $\begin{array}{c}-0.006^{* * *} \\
(0.002)\end{array}$ \\
\hline Risk & $\begin{array}{c}0.004 \\
(0.006)\end{array}$ & $\begin{array}{l}-0.005 \\
(0.014)\end{array}$ & $\begin{array}{c}0.008^{* * *} \\
(0.002)\end{array}$ & $\begin{array}{c}0.005 \\
(0.006)\end{array}$ & $\begin{array}{l}-0.004 \\
(0.014)\end{array}$ & $\begin{array}{c}0.008^{* * *} \\
(0.002)\end{array}$ \\
\hline Share & $\begin{array}{c}-0.000^{* * *} \\
(0.000)\end{array}$ & $\begin{array}{l}-0.000 \\
(0.000)\end{array}$ & $\begin{array}{c}-0.000^{* * * *} \\
(0.000)\end{array}$ & $\begin{array}{c}-0.000 * * * \\
(0.000)\end{array}$ & $\begin{array}{l}-0.000 \\
(0.000)\end{array}$ & $\begin{array}{c}-0.000 * * * \\
(0.000)\end{array}$ \\
\hline Mshare & $\begin{array}{l}0.007^{*} \\
(0.004)\end{array}$ & $\begin{array}{c}0.117^{* *} \\
(0.047)\end{array}$ & $\begin{array}{l}0.007^{* *} \\
(0.003)\end{array}$ & $\begin{array}{c}0.009 * * \\
(0.004)\end{array}$ & $\begin{array}{c}0.144^{* * *} \\
(0.043)\end{array}$ & $\begin{array}{c}0.010^{* * *} \\
(0.003)\end{array}$ \\
\hline CEO Duality & $\begin{array}{l}0.004^{* *} \\
(0.002)\end{array}$ & $\begin{array}{c}0.009 \\
(0.012)\end{array}$ & $\begin{array}{c}0.004^{* * *} \\
(0.001)\end{array}$ & $\begin{array}{c}0.004^{* *} \\
(0.002)\end{array}$ & $\begin{array}{c}0.008 \\
(0.012)\end{array}$ & $\begin{array}{c}0.004^{* * *} \\
(0.001)\end{array}$ \\
\hline Government Subsidies & $\begin{array}{c}1.013^{* * *} \\
(0.084)\end{array}$ & $\begin{array}{c}0.962^{* * *} \\
(0.162)\end{array}$ & $\begin{array}{c}1.030^{* * *} \\
(0.091)\end{array}$ & $\begin{array}{c}0.451^{* * *} \\
(0.127)\end{array}$ & $\begin{array}{c}0.193 \\
(0.272)\end{array}$ & $\begin{array}{c}0.482 * * * \\
(0.137)\end{array}$ \\
\hline Political Connection & $\begin{array}{c}0.005^{* *} \\
(0.002)\end{array}$ & $\begin{array}{l}0.006 \\
(0.006)\end{array}$ & $\begin{array}{c}0.004^{* *} \\
(0.002)\end{array}$ & & & \\
\hline $\begin{array}{l}\text { Government Subsidies * } \\
\text { Political Connection }\end{array}$ & $\begin{array}{c}-0.582 * * * \\
(0.133)\end{array}$ & $\begin{array}{l}-0.768^{* * *} \\
(0.205)\end{array}$ & $\begin{array}{c}-0.525^{* * *} \\
(0.148)\end{array}$ & & & \\
\hline Investor Attention & & & & $\begin{array}{l}-0.000 * * * \\
(0.000)\end{array}$ & $\begin{array}{l}-0.000 * * \\
(0.000)\end{array}$ & $\begin{array}{c}-0.000 * * \\
(0.000)\end{array}$ \\
\hline Government Subsidies * & & & & $0.001 * * *$ & $0.001 * *$ & $0.001 * * *$ \\
\hline Investor Attention & & & & $(0.000)$ & $(0.000)$ & $(0.000)$ \\
\hline Observations & 7174 & 2017 & 5157 & 7174 & 2017 & 5157 \\
\hline Year & YES & YES & YES & YES & YES & YES \\
\hline Industry & YES & YES & YES & YES & YES & YES \\
\hline Adjusted $\mathrm{R}^{2}$ & 0.212 & 0.120 & 0.316 & 0.204 & 0.119 & 0.306 \\
\hline
\end{tabular}

Robust standard errors shown in parentheses. ${ }^{* * *} p<0.01,{ }^{* *} p<0.05$, and ${ }^{*} p<0.1$.

Hypothesis 4 demonstrated that, compared with non-SOEs, the political connection of SOEs exerts a stronger weakening effect on the relationship between government subsidies and enterprise innovation. Model 5 (Table 3) showed that the coefficient for the interaction term was significant and negative $(\beta=-0.768, p<0.001)$. Moreover, Model 6 (Table 3 ) showed that the coefficient for the interaction term was significant and negative $(\beta=-0.525, p<0.001)$. The interaction coefficient of the sample of SOEs was significantly higher than that of non-SOEs, which supported Hypothesis 4.

Hypothesis 5 suggested that investor attention positively moderates the relationship between government subsidies and innovation investment. Model 7 (Table 3) showed that the coefficient for the interaction term was significant and positive $(\beta=-0.582, p<0.001)$ when other interactions were added to the model, thereby supporting Hypothesis 5 .

Finally, Hypothesis 6 proposed that, compared with non-SOEs, investors of SOEs focus more on the promotion of the relationship between government subsidies and enterprise innovation. Model 8 (Table 3) showed that the coefficient for the interaction term was significant and positive ( $\beta=-0.0010$, $p<0.01$ ). Moreover, Model 9 (Table 3) showed that the coefficient for the interaction term was significant and negative $(\beta=-0.0009, p<0.001)$. Furthermore, the interaction coefficient of the sample of SOEs was significantly higher than that of non-SOEs, which supported Hypothesis 6. 


\subsection{Discussion}

In order to understand the impact of public R\&D support on corporate R\&D activities, we explored data on listed companies in China's manufacturing industry. Through appropriate regression analysis to control the potential endogenous problems of R\&D intensity, we find that Chinese government subsidies have a significant positive incentive effect on the R\&D intensity of enterprises with different ownerships. Due to market failure and the incomplete adaptability of corporate R\&D mechanisms, it is difficult for the government to optimally allocate limited resources in the process of formulating $R \& D$ policies [3]. In view of the complexity of public resource allocation and the diversity of stakeholders, it is not easy to scientifically determine the enterprises that public R\&D projects should be supported [8]. The government's subsidy program is beneficial to companies that often successfully apply [21]. On the one hand, the government follows the principle of selecting excellent projects and promotes the maximum success rate of supported projects [29]. On the other hand, the government may consider the attempts of certain stakeholders to prioritize rent-seeking companies [25]. Under the mutual influence of these two factors, the government is likely to give priority to funding excellent $R \& D$ projects, while also considering projects with a relatively close political relationship [39].

The central difficulty faced by innovation-oriented enterprises is how to obtain financial investment promote the new product development and technology transformation [48]. In the less-developed countries, the early-stage speculative markets are often underdeveloped for experimental technologies and business efforts [35]. In view of the story of China being portrayed as a successful developing country, the "invisible hand" of the government plays the role of promoter in corporate R\&D activities, which plays an indispensable role in manufacturing development and industrial upgrading and transformation. However, the idea of economic manipulation for political purposes is not new [50]. Personal social relations and family networks play an important role in economic activities [56]. Politicians have more trust and goodwill towards people and organizations with whom they are closely related. Managers in companies may take personal gains because of their close relationship with a certain politician [53]. In order to meet the political promotion needs of politicians, corporate decision makers may use government subsidies to invest in projects that are not related to research and development [47]. At the same time, the government may invest in some worthless companies due to information asymmetry and bureaucratic incompetence [52]. In the case of imperfect external monitoring mechanisms, the transparency of these funding projects decided by government officials is not high, which gives them a lot of discretion [50]. Therefore, these factors fully explain the internal mechanism of the negative influence of political connections on corporate innovation.

Related projects funded by the government are considered to have relatively low investment risks [29]. The government's investment orientation not only helps investors filter out companies with low R\&D capabilities, but also establishes a good image for companies [72]. A government agency is considered more experienced in many past investment projects [76]. As indicators of lower investment risks, the projects with higher expected returns by the governments can attract the attention of external investors and receive more investment [70]. As the analysis becomes more in-depth and scientific, government agencies have better predictions on the focus and development trend of the project [78]. However, investors often only trade companies for which they know the information. Limited investor attention leads to classification learning behavior [73,74]. Therefore, investors tend to deal with public information within the market, rather than company-specific internal information. Baidu Search Index is considered to be the most direct and objective indicator to evaluate investors' attention [74]. Research shows that the attention of external investors has a positive effect on the growth and development of enterprises. Government subsidies are a good signal for private investment to increase corporate R\&D capital [68].

Consequently, our findings provide some support for the direction of government investment and the probability that companies can be funded by investors through innovative activities in the future. 


\section{Robustness Checks}

Overall, this study supported all of the hypotheses. However, we conducted several robustness checks to ensure the robustness of the results. First, we used industry-wide samples rather than listed companies' manufacturing samples to perform regression analysis on the hypotheses mentioned above. The results confirmed our hypotheses and further suggested that the relationships became more pronounced as the sample was concentrated in the more innovative manufacturing sector. Second, we used Tobin's $Q$ rather than ROE to validate the regression results of the hypotheses mentioned above. We calculated Tobin's $Q$ as the sum of the equity market value and the net debt market value divided by the total assets at the end of the period, and the non-tradable equity market value was replaced by net assets. All of these analyses also supported all of our hypotheses. Third, we considered whether a firm's debt ratio could play a role in describing the willingness to engage in R\&D investments. As debt financing exerts a tax shielding effect relative to equity financing, the higher the asset-liability ratio, the higher the financial risk faced by enterprises, and the resulting debt repayment pressure conflicts with the continuous demand for cash flow from innovative activities, which was suitable for our research. Moreover, we calculated the debt ratio as the firm's total liabilities divided by the total assets. We obtained the same results. Therefore, we are confident that our model specification did not bias our findings. The above results are shown in Tables 4 and 5 .

Table 4. Fixed-effect OLS regressions for the influence of government subsidies on innovation investment.

\begin{tabular}{|c|c|c|c|}
\hline & Model 10 & Model 11 & Model 12 \\
\hline Variables & All & SOES & NSOEs \\
\hline Constant & $\begin{array}{c}0.038^{* * *} \\
(0.005)\end{array}$ & $\begin{array}{c}0.022 \text { ** } \\
(0.009)\end{array}$ & $\begin{array}{c}0.046^{* * *} \\
(0.005)\end{array}$ \\
\hline Tobin's Q & $\begin{array}{c}0.006^{* * *} \\
(0.001)\end{array}$ & $\begin{array}{c}0.002 * * * \\
(0.001)\end{array}$ & $\begin{array}{c}0.006^{* * *} \\
(0.001)\end{array}$ \\
\hline Debt Ratio & $\begin{array}{c}-0.026^{* * *} \\
(0.006)\end{array}$ & $\begin{array}{l}-0.003 \\
(0.012)\end{array}$ & $\begin{array}{c}-0.037^{* * * *} \\
(0.007)\end{array}$ \\
\hline Solvency & $\begin{array}{l}-0.008 \\
(0.007)\end{array}$ & $\begin{array}{c}-0.037^{* * *} \\
(0.011)\end{array}$ & $\begin{array}{l}-0.003 \\
(0.009)\end{array}$ \\
\hline Current Ratio & $\begin{array}{c}0.001 * * * \\
(0.000)\end{array}$ & $\begin{array}{c}0.003^{* * *} \\
(0.001)\end{array}$ & $\begin{array}{c}0.001^{* * *} \\
(0.000)\end{array}$ \\
\hline Cash & $\begin{array}{c}-0.008^{* * *} \\
(0.002)\end{array}$ & $\begin{array}{l}-0.005 \\
(0.004)\end{array}$ & $\begin{array}{c}-0.011^{* * *} \\
(0.002)\end{array}$ \\
\hline Risk & $\begin{array}{l}0.006^{*} \\
(0.004)\end{array}$ & $\begin{array}{l}-0.000 \\
(0.008)\end{array}$ & $\begin{array}{c}0.011^{* * *} \\
(0.002)\end{array}$ \\
\hline Share & $\begin{array}{c}-0.000^{* * *} \\
(0.000)\end{array}$ & $\begin{array}{l}-0.000 \\
(0.000)\end{array}$ & $\begin{array}{c}-0.000^{* * *} \\
(0.000)\end{array}$ \\
\hline Mshare & $\begin{array}{c}0.013^{* * *} \\
(0.004)\end{array}$ & $\begin{array}{c}0.184^{* * *} \\
(0.057)\end{array}$ & $\begin{array}{c}0.011^{* * *} \\
(0.004)\end{array}$ \\
\hline CEO Duality & $\begin{array}{c}0.004^{* *} \\
(0.002)\end{array}$ & $\begin{array}{c}0.005 \\
(0.009)\end{array}$ & $\begin{array}{c}0.004^{* * *} \\
(0.001)\end{array}$ \\
\hline Government Subsidies & $\begin{array}{c}0.872 * * * \\
(0.082)\end{array}$ & $\begin{array}{c}0.774 * * * \\
(0.184)\end{array}$ & $\begin{array}{c}0.908^{* * *} \\
(0.088)\end{array}$ \\
\hline Observations & 8910 & 2736 & 6174 \\
\hline Year & YES & YES & YES \\
\hline Industry & YES & YES & YES \\
\hline Adjusted $\mathrm{R}^{2}$ & 0.248 & 0.119 & 0.316 \\
\hline
\end{tabular}

Robust standard errors shown in parentheses. ${ }^{* *} p<0.01,{ }^{* *} p<0.05$, and ${ }^{*} p<0.1$. 
Table 5. The moderation effect of political connection and investor attention on innovation investment.

\begin{tabular}{|c|c|c|c|c|c|c|}
\hline & Model 13 & Model 14 & Model 15 & Model 16 & Model 17 & Model 18 \\
\hline Variables & All & SOEs & NSOEs & All & SOEs & NSOEs \\
\hline Constant & $\begin{array}{c}0.037^{* * *} \\
(0.005)\end{array}$ & $\begin{array}{l}0.022 * * \\
(0.009)\end{array}$ & $\begin{array}{c}0.044^{* * *} \\
(0.005)\end{array}$ & $\begin{array}{c}0.041^{* * *} \\
(0.005)\end{array}$ & $\begin{array}{c}0.028^{* * *} \\
(0.009)\end{array}$ & $\begin{array}{c}0.046^{* * *} \\
(0.006)\end{array}$ \\
\hline Tobin's Q & $\begin{array}{c}0.006^{* * *} \\
(0.001)\end{array}$ & $\begin{array}{c}0.002^{* * *} \\
(0.001)\end{array}$ & $\begin{array}{c}0.006^{* * *} \\
(0.001)\end{array}$ & $\begin{array}{c}0.005^{* * *} \\
(0.001)\end{array}$ & $\begin{array}{c}0.002 * * * \\
(0.001)\end{array}$ & $\begin{array}{c}0.006^{* * *} \\
(0.001)\end{array}$ \\
\hline Debt Ratio & $\begin{array}{c}-0.027 * * * \\
(0.005)\end{array}$ & $\begin{array}{l}-0.003 \\
(0.012)\end{array}$ & $\begin{array}{c}-0.038^{* * *} \\
(0.006)\end{array}$ & $\begin{array}{c}-0.028^{* * *} \\
(0.006)\end{array}$ & $\begin{array}{l}-0.004 \\
(0.013)\end{array}$ & $\begin{array}{c}-0.039 * * * \\
(0.007)\end{array}$ \\
\hline Solvency & $\begin{array}{l}-0.007 \\
(0.006)\end{array}$ & $\begin{array}{c}-0.038^{* * *} \\
(0.011)\end{array}$ & $\begin{array}{c}0.000 \\
(0.009)\end{array}$ & $\begin{array}{l}-0.010 \\
(0.007)\end{array}$ & $\begin{array}{c}-0.039 * * * \\
(0.011)\end{array}$ & $\begin{array}{l}-0.008 \\
(0.010)\end{array}$ \\
\hline Current Ratio & $\begin{array}{c}0.001 * * * \\
(0.000)\end{array}$ & $\begin{array}{c}0.003 * * \\
(0.001)\end{array}$ & $\begin{array}{c}0.001 * * * \\
(0.000)\end{array}$ & $\begin{array}{c}0.001 * * * \\
(0.000)\end{array}$ & $\begin{array}{l}0.003 * * \\
(0.001)\end{array}$ & $\begin{array}{c}0.001 * * * \\
(0.000)\end{array}$ \\
\hline Cash & $\begin{array}{c}-0.008^{* * *} \\
(0.002)\end{array}$ & $\begin{array}{l}-0.005 \\
(0.004)\end{array}$ & $\begin{array}{c}-0.010^{* * *} \\
(0.002)\end{array}$ & $\begin{array}{c}-0.008^{* * * *} \\
(0.002)\end{array}$ & $\begin{array}{l}-0.005 \\
(0.004)\end{array}$ & $\begin{array}{c}-0.011^{* * *} \\
(0.002)\end{array}$ \\
\hline Risk & $\begin{array}{l}0.006^{*} \\
(0.004)\end{array}$ & $\begin{array}{l}-0.000 \\
(0.008)\end{array}$ & $\begin{array}{c}0.010^{* * * *} \\
(0.002)\end{array}$ & $\begin{array}{l}0.007^{*} \\
(0.004)\end{array}$ & $\begin{array}{l}-0.000 \\
(0.008)\end{array}$ & $\begin{array}{c}0.011^{* * *} \\
(0.002)\end{array}$ \\
\hline Share & $\begin{array}{c}-0.000 * * * \\
(0.000)\end{array}$ & $\begin{array}{l}-0.000 \\
(0.000)\end{array}$ & $\begin{array}{c}-0.000 * * * \\
(0.000)\end{array}$ & $\begin{array}{c}-0.000 * * * \\
(0.000)\end{array}$ & $\begin{array}{l}-0.000 \\
(0.000)\end{array}$ & $\begin{array}{c}-0.000 * * * \\
(0.000)\end{array}$ \\
\hline Mshare & $\begin{array}{c}0.012^{* * * *} \\
(0.004)\end{array}$ & $\begin{array}{c}0.178^{* * *} \\
(0.058)\end{array}$ & $\begin{array}{l}0.009 * * \\
(0.004)\end{array}$ & $\begin{array}{c}0.018^{* * *} \\
(0.004)\end{array}$ & $\begin{array}{c}0.201 * * * \\
(0.058)\end{array}$ & $\begin{array}{c}0.016^{* * *} \\
(0.004)\end{array}$ \\
\hline CEO Duality & $\begin{array}{c}0.004^{* *} \\
(0.002)\end{array}$ & $\begin{array}{c}0.006 \\
(0.009)\end{array}$ & $\begin{array}{c}0.004^{* * *} \\
(0.001)\end{array}$ & $\begin{array}{c}0.003 * * \\
(0.002)\end{array}$ & $\begin{array}{c}0.005 \\
(0.010)\end{array}$ & $\begin{array}{l}0.003^{* *} \\
(0.001)\end{array}$ \\
\hline Government Subsidies & $\begin{array}{c}1.082 * * * \\
(0.082)\end{array}$ & $\begin{array}{c}0.975^{* * *} \\
(0.176)\end{array}$ & $\begin{array}{c}1.131^{* * *} \\
(0.094)\end{array}$ & $\begin{array}{c}0.395^{* * *} \\
(0.116)\end{array}$ & $\begin{array}{c}0.056 \\
(0.228)\end{array}$ & $\begin{array}{c}0.451 * * * \\
(0.145)\end{array}$ \\
\hline Political Connection & $\begin{array}{c}0.005^{* *} \\
(0.002)\end{array}$ & $\begin{array}{c}0.004 \\
(0.004)\end{array}$ & $\begin{array}{c}0.005^{* * *} \\
(0.002)\end{array}$ & & & \\
\hline $\begin{array}{l}\text { Government Subsidies * } \\
\text { Political Connection }\end{array}$ & $\begin{array}{c}-0.659 * * * \\
(0.126)\end{array}$ & $\begin{array}{c}-0.785^{* * *} \\
(0.196)\end{array}$ & $\begin{array}{c}-0.636^{* * *} \\
(0.154)\end{array}$ & & & \\
\hline Investor Attention & & & & $\begin{array}{c}-0.000 * * * \\
(0.000)\end{array}$ & $\begin{array}{c}-0.000^{* * *} \\
(0.000)\end{array}$ & $\begin{array}{l}-0.000 \\
(0.000)\end{array}$ \\
\hline $\begin{array}{l}\text { Government Subsidies * } \\
\text { Investor Attention }\end{array}$ & & & & $\begin{array}{l}0.001^{* * *} \\
(0.000)\end{array}$ & $\begin{array}{l}0.001^{* * *} \\
(0.000)\end{array}$ & $\begin{array}{c}0.001 * * * \\
(0.000)\end{array}$ \\
\hline Observations & 8910 & 2736 & 6174 & 8910 & 2736 & 6174 \\
\hline Year & YES & YES & YES & YES & YES & YES \\
\hline Industry & YES & YES & YES & YES & YES & YES \\
\hline Adjusted $R^{2}$ & 0.263 & 0.135 & 0.333 & 0.255 & 0.139 & 0.323 \\
\hline
\end{tabular}

Robust standard errors shown in parentheses. ${ }^{* * *} p<0.01,{ }^{* *} p<0.05$, and ${ }^{*} p<0.1$.

\section{Conclusions}

Both academic scholars and policymakers concur on the significance of government subsidies in an economic system for cultivating creation and providing innovative resources. We developed our theoretical and empirical analyses for China's manufacturing industry as a sample and used data on A-share listed companies between 2011 and 2019. The entry point signifies the heterogeneous impact of government subsidies for companies with different ownerships on the corporate innovation input. By merging resource dependence theory and related stakeholder theory, we comprehensively analyzed the influence of political connection and investor attention on corporate innovation investment.

Overall, this study demonstrates that government subsidies received by enterprises significantly positively correlate with their innovation investment. Suitable government subsidies can promote enterprise innovation. In addition, after distinguishing between SOEs and non-SOEs, this positive impact persists significantly. The government's granting of R\&D subsidies to enterprises can minimize the $R \& D$ risks of enterprises and guarantee $R \& D$ funds for them, thereby encouraging enterprises to increase R\&D investment and enhance their innovation performance. In addition, continuous government subsidies for enterprises exert more significant incentive effects on enterprise innovation, and enterprises can increase their investment in innovation. Moreover, the empirical test revealed that political linkage debilitated the influence of government subsidies on the enterprise innovation input, and it was more apparent in non-SOEs. Furthermore, investors' attention promoted the impact of government subsidies on enterprise innovation investment, which is especially prominent among SOEs. 
This study not only theoretically extends the research on the influencing factors of government subsidies and enterprise innovation, but also furthers the theoretical research on government $R \& D$ subsidies, as well as supplements academic research on the resource dependence theory and related stakeholder theory. In addition, this study provides a new explanation for corporate innovation research from the viewpoint of political connections and investor attention. Regarding its practical significance, the study findings can help us to completely understand the different roles of government subsidies, political connections, and investor concerns in endorsing the transformation and upgrading of emerging economies in terms of innovation investment. We suggest that the government should focus on improving the R\&D subsidies policy, continuously optimizing the market competition environment, and promoting healthy competition among enterprises, so that government R\&D subsidies can truly and effectively encourage enterprises to achieve technological upgrades. Enterprises improve the innovation efficiency and ultimately result in a higher innovation performance. Finally, this study also elucidates disputes about government subsidies and has crucial policy implications on how to promote innovation through internal personnel resource management and external investment environment.

Although this article draws conclusions of theoretical and practical significance, there are still many shortcomings. First, we did not differentiate between the various effects of government R\&D subsidies and non-R\&D subsidies on enterprise innovation investment. Second, we did not include the political connection of the senior management team in the scope of influencing corporate decision-making; to a certain extent, this overlooks the financial resources that senior management brings to the company. Finally, among non-SOEs, private enterprises and family businesses, as the main operators, should be highly valued in future research. These issues will form the directions of our further research in the future.

Author Contributions: The manuscript was written with contributions from all authors. S.W. developed key research hypotheses, themes, and the methodology. S.Z. acquired funding wrote the first draft with D.S. and addressed the problems in the research. H.L. was involved in theoretical conception, empirical research design, and paper revision. S.W. contributed to the introduction, data collection, and formatting. All authors have read and agreed to the published version of the manuscript.

Funding: This research was funded by the National Key R\&D Program of China: Modern service industry key special project "R\&D and Application Demonstration of Comprehensive Technology Service Platform of Hachang City Group". Grant number: 2017YFB1401800.

Acknowledgments: The authors gratefully acknowledge Shukuan Zhao for useful discussions.

Conflicts of Interest: The authors declare that there are no conflicts of interest regarding the publication of this paper.

\section{References}

1. Katila, R.; Ahuja, G. Something old, something new: A longitudinal study of search behavior and new product introduction. Acad. Manag. J. 2002, 45, 1183-1194. [CrossRef]

2. Beck, M.; Lopes-Bento, C.; Schenker-Wicki, A. Radical or incremental: Where does R\&D policy hit? Res. Pol. 2016, 45, 869-883. [CrossRef]

3. Romer, P.M. Increasing returns and long-run growth. J. Polit Econ. 1986, 94, 1002-1037. [CrossRef]

4. Aghion, P.; Howitt, P. A model of growth through creative destruction. Econometrica 1992, 60, 323-351. [CrossRef]

5. Guellec, D.; Van Pottelsberghe De La Potterie, B. The impact of public R\&D expenditure on business R\&D. Ulb Inst. Repos. 2003, 12, 225-243. [CrossRef]

6. Hall, B.; Reenen, J.V. How effective are fiscal incentives for R\&D? A review of the evidence. Res. Pol. 2000, 29, 449-469. [CrossRef]

7. David, P.A.; Hall, B.H.; Toole, A.A. Is public R\&D a complement or substitute for private R\&D? A review of the econometric evidence. Res. Pol. 2000, 29, 497-529. [CrossRef]

8. Strobl, G.E. The effect of R\&D subsidies on private R\&D. Economica 2007, 74, 215-234. [CrossRef]

9. Hyytinen, A.; Toivanen, O. Do financial constraints hold back innovation and growth?: Evidence on the role of public policy. Res. Pol. 2005, 34, 1385-1403. [CrossRef] 
10. Barney, J. Firm resources and sustained competitive advantage. J. Manag. 1991, 17, 99-120. [CrossRef]

11. Collis, D.J.; Montgomery, C.A. Competing on resources-Strategy in the 1990s. Harv. Bus. Rev. 1995, 73, 118-128.

12. Priem, R.L.; Butler, J.E. Is the resource-based "view" a useful perspective for strategic management research? Acad. Manag. Rev. 2001, 26, 22-40. [CrossRef]

13. Conner, K.R. A historical comparison of resource-based theory and 5 schools of thought within industrial-organization economics-Do we have a new theory of the firm. J. Manag. 1991, 17, 121-154. [CrossRef]

14. Fama, E.F.; Jensen, M.C. Separation of ownership and control. J. Law Econ. 1983, 26, 301-325. [CrossRef]

15. Hermalin, B.E.; Weisbach, M.S. Endogenously chosen boards of directors and their monitoring of the ceo. Am. Econ. Rev. 1998, 88, 96-118. [CrossRef]

16. Czarnitzki, D.; Licht, G. Additionality of public R\&D grants in a transition economy. Econ. Transit. 2006, 14, 101-131. [CrossRef]

17. Montmartin, B.; Herrera, M. Internal and external effects of R\&D subsidies and fiscal incentives: Empirical evidence using spatial dynamic panel models. Res. Pol. 2015, 44, 1065-1079. [CrossRef]

18. Minniti, M. The role of government policy on entrepreneurial activity: Productive, unproductive, or destructive? Entrep. Theory Pract. 2008, 32, 779-790. [CrossRef]

19. Yadong, L. An organizational perspective of corruption. Manag. Organ. Rev. 2005, 1, 119-154. [CrossRef]

20. Lin, P.; Xiong, W. Investor attention, overconfidence and category learning. J. Finan Econ. 2006, 80, 563-602. [CrossRef]

21. Hirshleifer, D.; Lim, S.S.; Teoh, S.H. Limited investor attention and stock market misreactions to accounting information. Rev. Asset Pricing Stud. 2011, 1, 35-73. [CrossRef]

22. Drake, M.S.; Roulstone, D.T.; Thornock, J.R. Investor information demand: Evidence from google searches around earnings announcements. J. Acc. Res. 2012, 50, 1001-1040. [CrossRef]

23. Barney, J.B. Firm resources and sustained competitive advantage. J. Manag. 2009, 17, 3-10. [CrossRef]

24. Wernerfelt, B. A resource-based view of the firm. Strateg. Manag. J. 2010, 5, 171-180. [CrossRef]

25. Peteraf, M.A. The cornerstones of competitive advantage: A resource-based view. Strateg. Manag. J. 1993, 14, 179-191. [CrossRef]

26. Feldman, M.P.; Kelley, M.R. The exante assessment of knowledge spillovers: Government R\&D policy, economic incentives and private firm behavior. Res. Pol. 2006, 35, 1509-1521. [CrossRef]

27. García-Quevedo, J. Do public subsidies complement business R\&D? A meta-analysis of the econometric evidence. Kyklos 2010, 57, 87-102. [CrossRef]

28. Becker, B. Public R\&D policies and private R\&D investment: A survey of the empirical evidence. J. Econ. Surv. 2015, 29, 917-942. [CrossRef]

29. Czarnitzki, D.; Hand, P.; Rosa, J.M. Evaluating the impact of R\&D tax credits on innovation: A microeconometric study on Canadian firms. Res. Pol. 2011, 40, 217-229. [CrossRef]

30. Yang, C.H.; Huang, C.H.; Hou, C.T. Tax incentives and R\&D activity: Firm-level evidence from Taiwan. Soc. Sci. Electron. Publ. 2012, 41, 1578-1588. [CrossRef]

31. Carboni, O.A. R\&D subsidies and private R\&D expenditures: Evidence from Italian manufacturing data. Int Rev. Appl. Econ. 2011, 25, 419-439. [CrossRef]

32. Czarnitzki, D.; Ebersberger, B.; Fier, A. The relationship between R\&D collaboration, subsidies and R\&D performance: Empirical evidence from Finland and Germany. J. Appl. Econom. 2007, 22, 1347-1366. [CrossRef]

33. Nishimura, J.; Okamuro, H. Subsidy and networking: The effects of direct and indirect support programs of the cluster policy. Res. Pol. 2011, 40, 714-727. [CrossRef]

34. Lanahan, L. Multilevel public funding for small business innovation: A review of us state sbir match programs. J. Tech. Transf. 2016, 41, 220-249. [CrossRef]

35. Audretsch, D.B.; Link, A.N.; Scott, J.T. Public/private technology partnerships: Evaluating sbir-supported research. Res. Pol. 2002, 31, 145-158. [CrossRef]

36. Todlting, F.; Trippl, M. One size fits all?: Towards a differentiated regional innovation policy approach. Res. Pol. 2005, 34, 1203-1219. [CrossRef]

37. Spence, M. Cost reduction, competition and industry performance. Econometrica 1986, 52, 101-121. [CrossRef] 
38. Beck, T.; Demirguc-Kunt, A. Small and medium-size enterprises: Access to finance as a growth constraint. J. Bank. Financ. 2006, 30, 2931-2943. [CrossRef]

39. Giudici, G.; Paleari, S. The provision of finance to innovation: A survey conducted among Italian technology-based small firms. Small Bus. Econ. 2000, 14, 37-53. [CrossRef]

40. Lerner, J. The government as venture capitalist: The long-run effects of the SBIR program. J. Bus. 1996, 72, 285-318. [CrossRef]

41. Wallsten, S.J. The effects of government-industry R\&D programs on private R\&D: The case of the small business innovation research program. Rand J. Econ. 2000, 31, 82-100. [CrossRef]

42. Lach, S. Do R\&D subsidies stimulate or displace private R\&D? Evidence from Israel. J. Ind Econ. 2002, 50, 369-390. [CrossRef]

43. Takalo, T.; Tanayama, T.; Toivanen, O. Estimating the benefits of targeted R\&D subsidies. Rev. Econ. Statist. 2013, 95, 255-272. [CrossRef]

44. Zuniga-Vicente, J.A.; Alonso-Borrego, C.; Forcadell, F.J.; Galan, J.I. Assessing the effect of public subsidies on firm R\&D investment: A survey. J. Econ. Surv. 2014, 28, 36-67. [CrossRef]

45. Dimos, C.; Pugh, G. The effectiveness of R\&D subsidies: A meta-regression analysis of the evaluation literature. Res. Pol. 2016, 45, 797-815. [CrossRef]

46. de Blasio, G.; Fantino, D.; Pellegrini, G. Evaluating the impact of innovation incentives: Evidence from an unexpected shortage of funds. Ind. Corp. Chang. 2015, 24, 1285-1314. [CrossRef]

47. Czarnitzki, D.; Lopes-Bento, C. Innovation subsidies: Does the funding source matter for innovation intensity and performance? Empirical evidence from Germany. Ind. Innov. 2014, 21, 380-409. [CrossRef]

48. Guo, D.; Guo, Y.; Jiang, K. Government-subsidized R\&D and firm innovation: Evidence from China. Res. Pol. 2016, 45, 1129-1144. [CrossRef]

49. Gonzalez, X.; Jaumandreu, J.; Pazo, C. Barriers to innovation and subsidy effectiveness. Rand. J. Econ. 2005, 36, 930-950. [CrossRef]

50. Guo, D.; Jiang, K.; Kim, B.Y.; Xu, C. Political economy of private firms in China. J. Compar. Econ. 2014, 42, 286-303. [CrossRef]

51. Guariglia, A.; Liu, P. To what extent do financing constraints affect Chinese firms' innovation activities? Int. Rev. Finan. Anal. 2014, 36, 223-240. [CrossRef]

52. Veugelers, R.; Schneider, C. On young innovative companies: Why they matter and how (not) to policy support them. Ind corp change. Ind. Corp. Chang. 2008, 19, 969-1007. [CrossRef]

53. Carpenter, R.E.; Petersen, B.C. Capital market imperfections, high-tech investment, and new equity financing. Econ. J. 2002, 112, F54-F72. [CrossRef]

54. Berger, A.N.; Udell, G.F. The economics of small business finance: The roles of private equity and debt markets in the financial growth cycle. J. Bank. Financ. 1998, 22, 613-673. [CrossRef]

55. Binks, M.R.; Ennew, C.T. The relationship between U.K. Banks and their small business customers. Small Bus. Econ. 1997, 9, 167-178. [CrossRef]

56. Coad, A.; Rao, R. Innovation and firm growth in high-tech sectors: A quantile regression approach. Res. Pol. 2008, 37, 633-648. [CrossRef]

57. Edward Freeman, R.; Evan, W.M. Corporate governance: A stakeholder interpretation. J. Behav. Econ. 1990, 19, 337-359. [CrossRef]

58. Brandt, L.; Tombe, T.; Zhu, X. Factor market distortions across time, space and sectors in China. Rev. Econ. Dynam. 2013, 16, 39-58. [CrossRef]

59. Faccio, M. Politically connected firms. Amer. Econ. Rev. 2006, 96, 369-386. [CrossRef]

60. Goldman, E.; Rocholl, J.; So, J. Do politically connected boards affect firm value ? Rev. Finan Stud. 2009, 22, 2331-2360. [CrossRef]

61. Haiyang, L.I.; Zhang, Y. The role of managers' political networking and functional experience in new venture performance: Evidence from China's transition economy. Strateg. Manag. J. 2007, 28, 791-804. [CrossRef]

62. Jia, N. Are collective and private political actions substitutes or complements? Empirical evidence from China's private sector. Strateg. Manag. J. 2013, 35. [CrossRef]

63. Fisman, R. It's not what you know: Estimating the value of political connections. Amer. Econ. Rev. 2001, 91, 1095-1102. [CrossRef]

64. Johnson, S.; Mitton, T. Cronyism and capital controls: Evidence from Malaysia. J. Finan. Econ. 2003, 67, 351-382. [CrossRef] 
65. Sapienza, P. The effects of government ownership on bank lending. J. Finan. Econ. 2004, 72, 357-384. [CrossRef]

66. Faccio, M.; Masulis, R.W.; Mcconnell, J.J. Political connections and corporate bailouts. J. Financ. 2006, 61, 2597-2635. [CrossRef]

67. Bertrand, M.; Kramarz, F.; Schoar, A.; Thesmar, D. The cost of political connections. Rev. Financ. 2018, 22, 849-876. [CrossRef]

68. Stuart, T.; Wang, Y. Who cooks the books in China, and does it pay? Evidence from private, high-technology firms. Strateg. Manag. J. 2016, 37, 2658-2676. [CrossRef]

69. Nelson, R.R. The simple economics of basic economic research. J. Polit. Econ. 1959, 67, 297. [CrossRef]

70. Martin, S.; Scott, J.T. The nature of innovation market failure and the design of public support for private innovation. Res. Pol. 2000, 29, 437-447. [CrossRef]

71. Gans, J.S.; Hsu, D.H.; Stern, S. The impact of uncertain intellectual property rights on the market for ideas: Evidence from patent grant delays. Manag. Sci. 2008, 54, 982-997. [CrossRef]

72. Stiglitz, J.E.; Wallsten, S.J. Public-private technology partnerships-Promises and pitfalls. Am. Behav. Sci. 1999, 43, 52-73. [CrossRef]

73. Hellman, J.S.; Jones, G.; Kaufmann, D. Seize the state, seize the day: State capture and influence in transition economies. J. Compar. Econ. 2003, 31, 751-773. [CrossRef]

74. Taussig, M. Where is credit due? Legal institutions, connections, and the efficiency of bank lending in vietnam. Soc. Ence. Electron. Publ. 2008, 25, 535-578. [CrossRef]

75. Reinikka, R.; Svensson, J. Local capture: Evidence from a central government transfer program in Uganda. Quart. J. Econ. 2004, 119, 679-705. [CrossRef]

76. Aghion, P.; Van Reenen, J.; Zingales, L. Innovation and institutional ownership. Amer. Econ. Rev. 2013, 103, 277-304. [CrossRef]

77. Gordon, R.H.; Li, W. Government as a discriminating monopolist in the financial market: The case of China. J. Public Econ. 2003, 87, 283-312. [CrossRef]

78. Dobson, W.; Safarian, A.E. The transition from imitation to innovation: An enquiry into China's evolving institutions and firm capabilities. J. Asian Econ. 2008, 19, 301-311. [CrossRef]

79. Gompers, P.; Lerner, J. The venture capital revolution. J. Econ. Perspect 2001, 15, 145-168. [CrossRef]

80. Hsu, D.H.; Ziedonis, R.H. Resources as dual sources of advantage: Implications for valuing entrepreneurial-firm patents. Strateg. Manag. J. 2013, 34, 761-781. [CrossRef]

81. González, X.; Pazó, C. Do public subsidies stimulate private R\&D spending? Res. Pol. 2008, 37, 371-389. [CrossRef]

82. Aerts, K.; Schmidt, T. Two for the price of one?: Additionality effects of R\&D subsidies: A comparison between Flanders and Germany. Res. Pol. 2008, 37, 806-822. [CrossRef]

83. Meuleman, M.; De Maeseneire, W. Do R\&D subsidies affect SMEs' access to external financing? Res. Pol. 2012, 41, 580-591. [CrossRef]

84. Kleer, R. Government R\&D subsidies as a signal for private investors. Res. Pol. 2010, 39, 1361-1374. [CrossRef]

85. Cherniak, C. Human inference-Strategies and shortcomings of social judgment-Nisbett,r, ross,l. Philos. Rev. 1983, 92, 462-465. [CrossRef]

86. Repullo, R.; Suarez, J. Entrepreneurial moral hazard and bank monitoring: A model of the credit channel. Eur. Econ. Rev. 2000, 44, 1931-1950. [CrossRef]

87. Boeing, P. The allocation and effectiveness of China's R\&D subsidies-Evidence from listed firms. Res. Pol. 2016, 45, 1774-1789. [CrossRef]

88. Chen, S.; Bu, M.; Wu, S.; Liang, X. How does TMT attention to innovation of Chinese firms influence firm innovation activities? A study on the moderating role of corporate governance. J. Bus. Res. 2015, 68, 1127-1135. [CrossRef]

89. Cumming, D. Government policy towards entrepreneurial finance: Innovation investment funds. J. Bus. Ventur. 2007, 22, 193-235. [CrossRef]

90. Chan, L.K.C.; Lakonishok, J.; Sougiannis, T. The stock market valuation of research and development expenditures. J. Financ. 2001, 56, 2431-2456. [CrossRef]

91. Clausen, T.H. Do subsidies have positive impacts on R\&D and innovation activities at the firm level? Struct. Chang. Econ. Dyn. 2009, 20, 239-253. [CrossRef] 
92. Faccio, M. Politically-connected firms: Can they squeeze the state? Soc. Ence Electron. Publ. 2006, 96, 369-386(318). [CrossRef]

93. Bae, K.H.; Wang, W. What's in a "China" name? A test of investor attention hypothesis. Finan Manage. 2012, 41, 429-455. [CrossRef]

94. Vozlyublennaia, N. Investor attention, index performance, and return predictability. J. Bank. Financ. 2014, 41, 17-35. [CrossRef]

(C) 2020 by the authors. Licensee MDPI, Basel, Switzerland. This article is an open access article distributed under the terms and conditions of the Creative Commons Attribution (CC BY) license (http://creativecommons.org/licenses/by/4.0/). 